\title{
Langerhans cell histiocytosis; an institutional study
}

Karki Shovana ${ }^{1}$, Rajbhandari Aasia ${ }^{2}$

${ }^{I}$ Department of pathology, Tribhuvan University teaching hospital, Kathmandu, Nepal.

${ }^{2}$ Department of pathology, Tribhuvan University teaching hospital, Kathmandu, Nepal.

\section{Keywords:}

Bone;

Childhood;

Histiocytosis;

Langerhans cell

\section{ABSTRACT}

Background: Langerhans cell histiocytosis is a complex rare disease of the dendritic cell system. The disease can occur at any age, with a peak at 5-10 years. Here, we present the spectrum of this uncommon disease with different sites of involvement and its histopathological differential diagnosis.

Materials and Methods: Study included 24 cases of Langerhans cell histiocytosis out of approximately 50,000 biopsies received in the department.

Results: The male to female ratio was 1.6:1 with mean age of 12 years. Commonest site of involvement was skin $37.5 \%$, followed by bone $33.4 \%$. Lymph nodes $20.9 \%$, bone marrow $4.1 \%$ and thyroid $4.1 \%$ involvement was seen. Among the 9 cases of bone involvement, commonest site was humerus ( 3 cases), sternum ( 2 cases) and one case each in frontal bone, fibula, temporal bone and rib.

Conclusion: Langerhans cell histiocytosis should be considered in the differential diagnosis of histiocytic lesions involving various organs, especially in childhood.

\section{Correspondence:}

Dr. Shovana karki, MBBS, MD

Lecturer, Department of Pathology

Tribhuvan University teaching hospital, Kathmandu, Nepal.

ORCID ID: 0000-0001-5429-2422

Email: shovana_karki@hotmail.com

\section{Reveived : April 18th, 2017; Accepted : August 1st, 2017; Published : September 1, 2017}

Citation: Karki S, Rajbhandari A. Langerhans cell histiocytosis; an institutional study. J Pathol Nep. 2017;7: 1192-5. doi: 10.3126/jpn.v7i2.18032

Copyright: This is an open-access article distributed under the terms of the Creative Commons Attribution 4.0 International License, which permits unrestricted use, distribution, and reproduction in any medium, provided the original author and source are credited.

\section{INTRODUCTION}

Langerhans cell histiocytosis $(\mathrm{LCH})$ is a complex rare disease of the dendritic cell system with unpredictable progression. ${ }^{1}$ The disease can occur at any age, but a peak is seen at 5-10 years. The etiology remains to be elucidated with unknown pathogenesis. However, recently some have implied an association between LCH and genetic component. Increase incidence of the disease is seen with family history and a higher incidence is seen in monozygotic twins. ${ }^{2}$ The annual incidence of the disease is estimated at 1 in 200,000 individuals at risk in a study carried out in Japan. ${ }^{3}$ 
Clinical presentation and course of the disease is variable, ranging from isolated self-healing skin or bone lesions to disseminated disease with immense tissue damage. Here, we present the spectrum of this uncommon disease with different sites of involvement and discussion of its histopathological differential diagnosis.

\section{MATERIALS AND METHODS}

This is a retrospective study carried out in the department of pathology, IOM TUTH. Permission from institutional review committee was obtained. Data was collected from the archives in the department from April 2010 to April 2017. Relevant information was obtained from the information on the requisite form. SPSS vs16 was applied for statistical analysis.

\section{RESULTS}

This seven years study included 24 cases of LCH out of approximately 50,000 biopsies received in the department during that time. The male to female ratio was 1.6:1. The age of the cases ranged from 45 days to 44 years with a median age of 12 years. The most common site of involvement was skin $37.5 \%$, followed by bone $33.4 \%$. Other organs involved were lymph nodes $20.9 \%$, bone marrow $4.1 \%$ and thyroid $4.1 \%$. Diagnosis was made on biopsies which showed typical Langerhans cells (fig.1). Immunohistochemistry performed on 12 of these cases (S-100) was positive (fig. 2).

Other immunohistochemical markers were not available, hence, they were not done. Out of 5 cases (20.9\%) of lymph node involvement, cervical lymph node was involved in 3 cases. Axillary and inguinal lymph node involvement was seen in one case each.

Among the 9 cases of bone involvement the most common site was humerus ( 3 cases), sternum ( 2 cases) and one case each in frontal bone, fibula, temporal bone and rib.

\section{DISCUSSION}

Langerhans cell histiocytosis is characterized by proliferation of Langerhans type cells that have in common immunophenotypic and ultra-structural properties similar to antigen presenting Langerhans cells of mucosa and skin. ${ }^{3}$ Contrary to the belief that LCH originated from epidermal langerhans cells, recent studies using cell-specific gene expression profiling imply that the disease originates from bone marrow derived immature myeloid dendritic cells. ${ }^{4}$

Langerhans cell histiocytosis is seen mostly in children. In this study, 17 cases $(70.8 \%)$ were seen in children with a median age of 12 years. In a study by Sieni et al. the median age of patient was 8.7 years with 16 males and 11 females. ${ }^{1}$ The incidence of the disease is ten times less in adults with a mean in the thirties and only 10 percent above 55 years of age are affected by the disease. ${ }^{5}$ In this study $29.2 \%$ were adults. Maximum age at presentation was 44 years. This study also showed slight male predominance. Others have stated a $\mathrm{M}: \mathrm{F}$ of $3.7: 1 .^{2}$

Most of the cases present as uni or multifocal bone lesions whereas visceral involvement is uncommon. ${ }^{6}$ The frequently affected visceral organs are lungs followed by skin and lymph nodes. ${ }^{6}$ A rare case of $\mathrm{LCH}$ of thyroid was seen in this study. Langerhans cell histiocytosis of thyroid has been reported in literature. ${ }^{7}$ Langerhans cell histiocytosis of thyroid with cervical involvement and associated metastatic thyroid papillary cancer has also been reported. ${ }^{2}$

Langerhans cell histiocytosis encompass the previous three classifications including eosinophilic granuloma, HandSchuller-Christian and Letterer-Sieve. ${ }^{8}$

The LCH study group, classified the disease into single system LCH and multisystem LCH (MS-LCH) in $1990 .{ }^{8}$ The single system LCH can be divided into single site (single bone, skin or lymph node) and multiple site (multifocal bone and lymph nodes) forms. MS-LCH involved more than two organs at the time of diagnosis. ${ }^{9}$

MS-LCH is further subdivided into low risk and high risk forms. Low risk cases have no involvement of high-risk organs like liver, lungs, spleen and hematopoietic system. Involvement of these organs places the patient in higher risk group. ${ }^{9}$

In this study, multisystem LCH was not found. $\mathrm{LCH}$ commonly involves bone and skin but can involve any organ or site. Occasional reports of gastrointestinal involvement in $\mathrm{LCH}$ have been found in literature. ${ }^{10}$

The involvement of liver in children is high (19-60\%) has a poor prognosis. Though rare in adults, case reports of liver involvement in adults are found which carry a worse prognosis and a fatality rate of $30 \% .{ }^{11}$ Involvement of brain by $\mathrm{LCH}$ too has been reported. ${ }^{12}$ Cases of $\mathrm{LCH}$ followed by Hodgkin lymphoma ${ }^{13}$ and acute myeloid leukemia ${ }^{14}$ are found.

Langerhans cell histiocytosis occurring before and after malignancies i.e. AML, ALL, solid tumors like lymphoma, retinoblastoma, lung carcinoma, ependymoma, hepatocellular carcinoma, skin tumors, etc. have been reported. ${ }^{14}$

The diagnosis of LCH may be delayed due to its wide clinical presentations. Its diagnosis depends on the histopathological and immunophenotypic examination of biopsies from the lesion. The main feature is the morphologic identification of the characteristic LCH cells. ${ }^{15}$ The lesions contain 


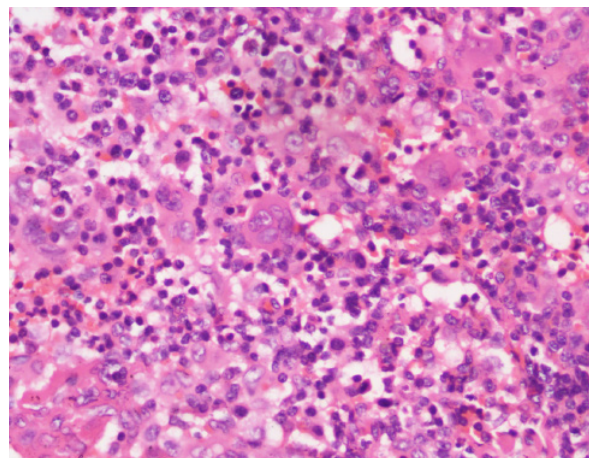

Figure 1: Typical Langerhans cells in a background of inflammatory cells from a scalp lesion (HE stain, X 100).

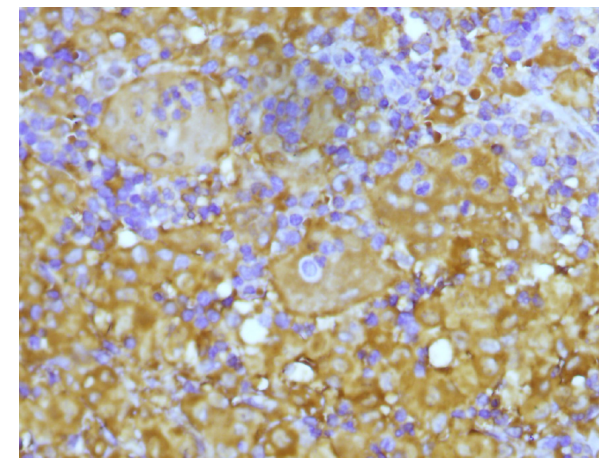

Figure 2: Langerhans cells positive for S-100 (Immunohistochemistry, X100). variable degree of macrophages, lymphocytes, eosinophils, giant cells and occasionally neutrophils and plasma cells. Langerhans cell histiocytosis cells are positive for CD1a, S100 and Langerin(CD207). ${ }^{15,16}$ Birbeck granules are found in $\mathrm{LCH}$ cells. ${ }^{16}$

The differential diagnosis in dermal LCH includes congenital histiocytomas, juvenile xanthogranuloma and xanthoma disseminatum, dermal histiocytomas. The differential diagnosis in lymph node involvement is dermatopathic lymphadenopathy ${ }^{16}$ and Rosai-Dorfman disease characterized by generalized massive lymphadenopathy and systemic symptoms. ${ }^{15}$

The prognosis of LCH depends on age of onset, number of organ involved, organ dysfunction and severity of the disease. ${ }^{17}$

\section{CONCLUSION}

Langerhans cell histiocytosis is a rare proliferative disease of histiocyte like cells that mostly affects pediatric age group. Diagnosis is made on the basis of clinical manifestation, along with features of imaging and histopathological analysis. Certain cases can undergo spontaneous regression, while others require systemic chemotherapy.

This rare disease should be considered in the differential diagnosis of histiocytic lesions involving various organs, especially in childhood.

\section{Conflict Interest: None}

\section{REFERENCES}

1. Øystein Fluge, Kristin Risa, Sigrid Lunde, et al. B-Lymphocyte Depletion in Myalgic Encephalopathy/ Chronic Fatigue Syndrome. An Open-Label Phase II Study with Rituximab Maintenance Treatment. PLOS ONE 10(7):e0131635. Crossref
2. A. Bahar Ceyran, Serkan Şenol, Barış Bayraktar, Şeyma Özkanlı, Z. Leyla Cinel, and Abdullah Aydın, "Langerhans Cell Histiocytosis of the Thyroid with Multiple Cervical Lymph Node Involvement Accompanying Metastatic Thyroid Papillary Carcinoma," Case Reports in Pathology, vol. 2014, Article ID 184237, 5 pages, 2014. Crossref

3. Horibe K, Saito AM, Takimoto T, Tsuchida M, Manabe A, Shima $\mathrm{M}$ et al. Incidence and survival rates of hematological malignancies in Japanese children and adolescents (2006-2010): based on registry data from the Japanese Society of Pediatric Hematology Int. J. Hematol. 2013;98:74-88. Crossref

4. Harmon CM, Brown N, Langerhans cell histiocytosis. A clinicopathologic review and molecular pathogenetic update. Arch Pathol 2015;139:1211-3. Crossref

5. Arico M, Girschikofsky T, Genereau. Langerhans cell histiocytosis in adults. Report from international registry of histiocyte society. Eur. J. Cancer. 2003; 39:2344-8. Crossref

6. Bi L, Sun B, Lu Z, Shi Z, Wang D, Zhu Z. Langerhans cell histiocytosis with multisystem involvement in an infant: A case report. Exp Ther Med . 2015; 9:2137-40. Crossref

7. Patten DK, Wani Z, Tolley N. Solitary Langerhans histiocytosis of the thyroid gland: a case report and literature review. Head and neck pathology 2012;6:279-89. Crossref

8. Abla O, Egeler RM and Weitzman S. Langerhans cell histiocytosis: Current concepts and treatments, Cancer Treat Rev 2010; 36:354-9. Crossref

9. Allen CE, McClain KL. Lanherhans cell histiocytosis: a review of past, present and current and future therapies. Drugs today (Bare) 2007;43:627-43. Crossref

10. Hait E, Liang M, Degar B, Glickman J, Fox VL. Gastrointestinal tract involvement in Langerhans cell histiocytosis: Case report and literature review. Pediatrics 2006;118:1593-8. Crossref 
11. Bruno Araujo, Francisco Costa, Joanne Lopes, and Ricardo Castro. Adult Langerhans Cell Histiocytosis with Hepatic and Pulmonary Involvement. Case Reports in Radiology 2015. Article ID 536328, 4 pages, 2015. Crossref

12. Dardis C, Aung T, Shapiro W, Fortune J, Coons S. Langerhans cell histiocytosis in an adult with involvement of the calvanium, cerebral cortex and brainstem: Discussion of pathophysiology and rationale for the use of intravenous immune globulin. Case Rep Neurol 2015;7:30-8. Crossref

13. Safaei A, Shahryari J, Noori S, Esmailzade E. Langerhans cell histiocytosis followed by Hodgkin Lymphoma: A case report. IJMS 2015;40:282-6. Crossref
14. Xu G, Yang M, Juang J, Jin J. Successful treatment of a case of Acute Myeloid Leukemia following Langerhans cell histiocytosis in an adolescent: A case report and review of literature. Int. J, Clin Exp Med 2015;8:3024-6. Crossref

15. Balzewicz I, Biernat W, Kowalczyk A, Baranska-Rybak W, Nowicki $\mathrm{R}$, Stawczwyk-Macieja $\mathrm{M}$ et al. Adult onset of multisystem Langerhans cell histiocytosis with skin and lymph node involvement. Postep Derm Alergol 2015;3:225-8. Crossref

16. Favara EB, Jaffe R. The histopathology of Langerhans cell histiocytosis. Br. J. Cancer 1994;70:17-23.

17. Lahey ME, Prognostic factors in histiocytosis X. Am J Pediatr Hematol Oncol 1981;3:57-60. Crossref 